\title{
INTERDYSCYPLINARNE ASPEKTY TEOLOGICZNEJ OBRONY RODZINY
}

Zwrócenie uwagi na interdyscyplinarne aspekty w dyskursie o współczesnym kryzysie rodziny ma swoje uzasadnienie zarówno w świadomości współczesnych rodziców, jak i w charakterystyce myśli teologiczno-moralnej ks. prof. S. Olejnika. Profesor jako uczeń prof. Z. Kozubskiego, od początku swojej działalności naukowej miał świadomość konieczności dialogu teologii moralnej nie tylko z innymi naukami teologicznymi, ale także z wynikami współczesnych nauk o człowieku.

Poprzez swój podręcznik Dar - Wezwanie - Odpowiedź oraz wiele innych prac naukowych, przyczynił się do wygrania w Polsce po II wojnie światowej kilku podstawowych batalii o kształt naszej świadomości moralnej. Dotyczy to zwłaszcza obrony moralności chrześcijańskiej przed marksizmem i etyką ateistyczną, a także obrony katolickiego modelu etyki małżeńskiej, atakowanej zwłaszcza po $1968 \mathrm{r}$. W pierwszej sprawie niebagatelną rolę odegrała rozprawa habilitacyjna Księdza Profesora ${ }^{1}$. W obronie katolickiego modelu rodziny, zarysowanego w Humanae vitae, ks. S. Olejnik ściśle współpracował z kard. K. Wojtyłą, swoim serdecznym przyjacielem² ${ }^{2}$.

1 Por. S. O le j n i k, Eudajmonizm. Studium nad podstawami etyki, Warszawa 1954.

2 Por. I. M r o c z k ow s k i, Ocena dorobku naukowego i działalności na rzecz nauki i kultury chrześcijańskiej Księdza Profesora Stanisława Olejnika w związu 
Jan Paweł II był nie tylko świadom kryzysu współczesnej rodziny, ale inspirował chrześcijańskie myślenie i działanie w obronie rodziny. W swoim nauczaniu poruszał trzy zespoły zagadnień, wokół których mogą się skupić także współczesne programy studiów oraz idących za nimi działań duszpasterskich. Papież wymieniał je, zadając następujące pytania: „Czyż można (...) zrezygnować z refleksji nad <zjawiskiem ludzkim> ukazanym przez różne dyscypliny naukowe? Czy można zarzucić studia nad wolnością - podstawą wszelkiej antropologii, która otwiera drogę do najgłębszych pytań ontologicznych? Czy można obyć się bez teologii, w której natura, wolność i łaska są postrzegane jako wielokształtna jedność w świetle tajemnicy Chrystusa? Tu właśnie znajdujemy syntezę (...), jako że <tajemnica człowieka wyjaśnia się naprawdę dopiero w tajemnicy Słowa wcielonego> (KDK 22)"3.

To właśnie w odniesieniu do życia rodzinnego istotne okazują się odpowiedzi na temat statusu ontologicznego podmiotów życia rodzinnego, współczesnych uwarunkowań wzajemnych relacji małżonków chrześcijańskich, czy wreszcie kościelnej strategii obrony rodziny. Realizm takiej perspektywy badawczej potwierdzają również przedstawiciele współczesnych nauk o człowieku, badający chociażby kryzys ojcostwa. Ph. Zimbardo, głos i twarz współczesnej psychologii, pisze, że ,jeśli chcemy zrozumieć i wyjaśnić złożone zachowania ludzi, to konieczne jest odwołanie się do analizy trzypoziomowej: po pierwsze, jaki wkład w kontekst behawioralny ma jednostka - jej cechy i stale charakterystyki; następnie należy przeanalizować, jakie zachowania prowokuje sytuacja związana z konkretnym społecznym czy fizycznym środowiskiem, w którym człowiek je ujawnia;

z nadaniem doktoratu honoris causa, w: Ks. abp prof. Alfons Nossol ks. prof. Stanisław Olejnik. Doktorzy honoris causa i Papieskiego Wydziału Teologicznego we Wrocławiu, Wrocław 2007, s. 48.

3 J a n P a w eł II, Ojcostwo i macierzyństwo w zamyśle Bożym, „L'Osservatore Romano" (wyd. pol.), 1999 nr 11, s. 11-13. 
i w końcu, w jaki sposób leżący u ich podstaw układ sił tworzy, podtrzymuje lub modyfikuje owe sytuacja"4.

W teologiczno-duszpasterskiej perspektywie badawczej, w której umieszczamy nasz artykuł, przekłada się to na konieczność uwzględnienia osobowej natury kobiet i mężczyzn (1), krytycyzm wobec redukcjonistycznego opisu sytuacji rodziny przez współczesne nauki (2) oraz eklezjalny charakter układu sił, tworzących strategię obrony rodziny (3).

\section{OBRONA OSOBOWEJ NATURY KOBIETY I MĘŻCZYZNY ${ }^{5}$}

Szukając podstaw antropologicznych rodziny, trzeba podkreślić ważną rolę refleksji nad zjawiskiem ludzkim, ukazywanym przez współczesne dyscypliny naukowe. Perspektywę taką rysuje Jan Paweł II, który jest przekonany, iż w wielu dziedzinach współczesnej wiedzy o człowieku można znaleźć ważne elementy, które pozwalają zrozumieć ,zjawisko ludzkie”. Da się ono nie tylko zintegrować z kierunkiem myślenia antropologii chrześcijańskiej, ale wprost powinno stać się jej składnikiem ${ }^{6}$.

Terenem współczesnej dyskusji na temat antropologii filozoficzno - teologicznej dialogującej z wynikami nauk o człowieku, jest teologia moralna, w ramach której wciąż stawiane są pytania o prawo naturalne, sumienie, rodzinę, nie wspominając o bioetyce. Nie jest przypadkiem, że dyskusje teologów moralistów po Humanae vitae dały asumpt do refleksji nad biologizmem prawa natury i miejscem ciała w kwestiach prawa naturalnego. Ważne w tym aspekcie są szczególnie dwa dokumenty: encyklika Veritatis splendor oraz cykl

${ }^{4}$ Ph.G. Z i m b a r d o, N.S. C o u 1 o m b e, Gdzie ci mężczyźni, (tłum. M. Guzowska), Warszawa 2015, s. 12.

5 W opracowaniu tematu wykorzystano pracę: I. M r o c z k o w s k i, Rodzina, gender i nowy feminizm. Podstawy chrześcijańskiej obrony i promocji rodziny, Płock 2014, s. 40-56.

${ }^{6}$ Por. I. M r o c z k o w s k i, Natura osoby ludzkiej. Podstawy tożsamości człowieka, Płock 2012, s. 11-12. 
katechez środowych, w których Jan Paweł II sformułował założenia teologii ciała. W Veritatis splendor Papież mówi o naturze osoby ludzkiej jako jedności duszy i ciała, czyli wszystkich skłonnościach, zarówno duchowych jak i biologicznych oraz wszelkich innych właściwościach, „które są jej niezbędne, by mogła dążyć do swego celu”’ Takie ujęcie natury osoby ludzkiej jest niezwykle pomocne nie tylko w określaniu istoty zjawiska ludzkiego, ale powinno dać wiele do myślenia w dyskusji na temat plci kulturowej.

$\mathrm{Z}$ jednej strony nie można zgodzić się z tym, że „współrzędne czasoprzestrzenne świata postrzegalnego zmysłowo, stałe fizyczno-chemiczne, siły cielesne, skłonności psychiczne i uwarunkowania społeczne to jedyne czynniki, które mają naprawdę decydujący wpływ na ludzką rzeczywistość"8. Z drugiej strony należy mocno podkreślić, że „dyscypliny naukowe określane wspólnym mianem $<$ nauk o człowieku> słusznie zwróciły uwagę na uwarunkowania natury psychologicznej i społecznej, które wpływają na sposób, w jaki człowiek korzysta z wolności"'. Ma to bezpośrednie znaczenie dla poprawnego ujęcia płciowości człowieka i jej kulturowego wyrazu, co zdaje się zakładać gender. Czyż zasadniczym problemem tzw. społeczno-kulturowej tożsamości płciowej, nie jest dostateczna refleksja nad sposobem zakorzenienia wiedzy seksuologicznej na temat płci w odpowiednio pogłębionym znaczeniu kultury?

Jeśli zgodnie z teorią gender, role seksualne, zachowania $i$ atrybuty właściwe dla kobiet i mężczyzn tworzone sa przez społeczeństwo, to zasadnicze pytanie brzmi: czy powinny liczyć się z biologicznymi i psychicznymi elementami seksualności ludzkiej? Czy też pozostają całkowicie od nich niezależne. Pytania te stawia m. in. B. Szacka. Powołując się na badania seksuologów, ${ }^{10}$ wymienia dziesięć kryteriów

\footnotetext{
7 J a n P a w ełII, Veritatis splendor. Oniektórych podstawowych problemach nauczanie moralnego Kościoła, nr 48, Watykan 1993.

8 Por. tamże, nr 46.

9 Tamże, nr 33.

10 B. Szacka w cytowanym wcześniej artykule Gender i płeć powołuje się na S. Dulko i jego artykuł: $A B C \ldots . . p t c i$, „Kosmos”, t. 52 nr 1, s. 5-10.
} 
płciowości, spośród których „dwa można uznać za związane z płcią kulturową: płeć psychiczna (poczucie przynależności do danej płci) i płeć społeczna - ustalona po urodzeniu na podstawie budowy zewnętrznych narządów płciowych - która określa przynależność do kategorii mężczyzn lub kobiet i wyznacza związane z nią role społeczne. Pozostałe osiem jest związanych z biologią i jest to: płeć chromosomalna, określona przy zapłodnieniu przez chromosomy płciowe (kobiety XX, mężczyźni XY); płeć gonadalna, zaznaczona od 7 tygodnia po zapłodnieniu, wyznaczona przez gruczoły płciowe, jądra i jajniki; płeć wewnętrznych narządów płciowych - polegająca na różnicy dróg rozrodczych; płeć zewnętrznych narządów płciowych; płeć hormonalna - polegająca na odmiennym poziomie męskich i żeńskich hormonów; płeć fenotypowa określana przez zewnętrzny wygląd człowieka, czyli drugo- i trzeciorzędowe cechy płciowe; płeć metaboliczna - określana przez rodzaj aparatu enzymatycznego niektórych systemów metabolicznych; płeć mózgowa - polega na typowo płciowym zróżnicowaniu mózgu"11.

Jest to zgodne z ujęciem Imielińskiego, który definiuje płeć jako „zespół cech odróżniających w obrębie gatunku organizmy żeńskie, wytwarzające komórki jajowe, od organizmów męskich, wytwarzających plemniki. Cechy pierwszorzędowe płciowe to gruczoły rozrodcze, cechy drugo- i trzeciorzędowe to np. gruczoły mleczne samic, poroże samców jelenia, zarost mężczyzny"12. Ten sam autor wyraźnie stwierdza, że choć fizjologia jest warunkiem seksualności człowieka, to ,seksualność jest wyrazem osobowości, dlatego wszelkie odczucia, reakcje i zachowania seksualne, uwarunkowane istnieniem popędu seksualnego należy rozpatrywać na tle całości, jaką jest człowiek"13. Tak więc w refleksji nad płciowością mężczyzny i kobiety, a w konsekwencji nad istotą małżeństwa i rodziny, kluczem pozostaje rozumowe ujęcie istoty seksualności mężczyzny i kobiety.

\footnotetext{
11 B. S z a c k a, Gender i płeć, dz. cyt., s. 26.

${ }^{12}$ K. I m i el i ń s k i (red.), Seksuologia. Zarys encyklopedyczny, Warszawa 1985 , s. 266.

13 Tamże, s. 279.
} 
Zakłada ono interpretację celowości rozrodczej popędu seksualnego, jego społecznie uwarunkowaną artykulację, nieodłączną od psychicznych i duchowych wymiarów osoby ludzkiej.

Nie można zrozumieć seksualności człowieka bez osobowo-jednoczącego ujęcia jego biologii, psychiki i duchowości. Wszystkie te warstwy zawarte są w pojęciu natury osoby ludzkiej. W przeciwieństwie do nurtów materialistycznych i idealistycznych - nie wyklucza się tu żadnego wyznacznika płciowości ludzkiej, lecz chce się je zintegrować w strukturze osoby. Słowo natura pochodzi od łacińskiego słowa nascor - rodzić się. Niesie więc w sobie konotację biologiczno-naturalną, złączoną zresztą z pojęciem procesu czasowego. To w niej filozofowie greccy szukali czegoś istotnego, czegoś, co się nie zmienia w procesie życia i w historii. Tak więc w istocie płciowości kobiety i mężczyzny trzeba odkryć sensowność posiadanej przez nich zdolności rozrodczej, fascynacji seksualnej i zdolności do wzajemnego poświęcenia w miłości ${ }^{14}$.

Współczesne oddzielenie sfery biologicznej, psychicznej i duchowej w przeżywaniu ludzkiej seksualności nie ułatwia szukania tego, co w niej istotne. Ma to bezpośrednie konsekwencje w budowaniu tożsamości męskiej i kobiecej. Tożsamość zakłada nie tylko bycie tym samym, a więc posiadaczem określonego zestawu cech biologicznych męskich lub kobiecych. Tożsamość mężczyzny i kobiety to przede wszystkim bycie soba, które wyraża się w podmiotowym, zgodnym z własnym sumieniem, braniem odpowiedzialności za własną męskość i kobiecość. To także świadoma i wolna relacje między kobietą i mężczyzną w małżeństwie, łącznie z owocem tej relacji - dzieckiem. Niebagatelną rolę odgrywają tu stosunki społeczno - polityczno - kulturowe, w jakich dokonuje się ekspresja płciowości. W żadnym razie różnica płciowa między mężczyzną i kobietą nie może przekształcić się w ich nierówność ontologiczną, społeczno - ekonomiczną czy kulturową.

14 Por. Ks. I. M r o c z k o w s k i, Osoba i cielesność. Moralne aspekty teologii ciała, Warszawa 2008, s. 204- 223. 
Integracja różnych sfer płciowości jest owocem namysłu filozoficzno-antropologicznego, której dokonuje każdy człowiek na podstawie przyjmowanych przez siebie wyborów światopoglądowych. Wielu współczesnym ujęciom filozoficzno-antropologicznym grozi redukcjonizm materialistyczny albo idealistyczny. W pierwszym wypadku integracja seksualności ogranicza się do poznania i wykorzystania wiedzy biologiczno-przyrodniczej. Z taką praktyką mamy do czynienia w niektórych wersjach wychowania seksualnego. $Z$ drugiej strony, nie należy uciekać w jakiś idealizm kulturowy, który pozostawia na boku sferę biologiczną człowieka. Z taką praktyką mamy do czynienia w teorii gender. W istocie powinniśmy nie tylko odpowiedzieć na pytanie, jak funkcjonuje ludzka płciowość, ale przede wszystkim, jaki ma ona sens w osobistym i społecznym kontekście.

W odpowiedzi na to pytanie chrześcijaninowi pomaga współczesny personalizm. Samo pojęcie osoby (łac. persona) zasadniczo skrystalizowało się w myśli chrześcijańskiej w kontekście refleksji nad tajemnicą Trójcy Świętej i natury Jezusa Chrystusa ${ }^{15}$. Odkąd Boecjusz nauczył nas, że osoba jest indywidualna substancją natury rozumnej, podmiotowość człowieka związana została z racjonalnym i wolnym sposobem istnienia biologiczno-psychicznej struktury człowieka ${ }^{16}$. Używając współczesnego języka, można powiedzieć, że osoba jest rozumnym, wolnym i zdolnym do miłości sposobem istnienia biologiczno-psychicznej struktury człowieka. Szuka ona obiektywnego

15 Por. tamże, s. 13; J. R a t z i n g e r, Dogma und Verkündigung, München 1977, s. 201-202.

${ }^{16}$ Droga od Boecjuszowej definicji osoby i jej aplikacji teologicznej do współczesnego personalizmu jest długa i nie ma tutaj miejsca, aby ją przypominać. Zwłaszcza, że ,jedne określenia osoby poszły nieco po linii <natury> (substancji), inne bardziej po linii <egzystencji > (relacji). Pierwsze podkreślały niezależność, całkowitość w sobie, posiadanie siebie, istnienie w sobie i przez siebie; drugie zaś główną uwagę zwracały na relacjonalność, otwartość i komunikatywność. Pierwsze raczej brały pod uwagę odmienność osób ludzkich w stosunku do osób Bożych; drugie starały się akcentować, że to, co istotne dla Osób Bożych, nie może nie być istotne dla osób ludzkich.” T. W i 1 s k i, ,Tajemnica osoby”-klucz do zrozumienia siebie i Boga, „Communio. Międzynarodowy Przegląd Teologiczny”, 1982 nr 2(8), s. 28. 
(prawdziwego) sensu życia, zdolna jest do podmiotowego bycia sobą, w solidarnej i sprawiedliwej harmonii z innymi osobami.

Osoba jest rozumnym sposobem namysłu nad własną płcią biologiczną. Oznacza to nie tylko zdolność do poznania struktury biologiczno - psychicznej płciowości. Rozumność oznacza także namysł nad znaczeniem płciowości w realizacji celów życiowych osoby. Rzetelny namysł nie może pominąć komplementarności płciowości na płaszczyźnie biologicznej, psychicznej i duchowej. Odkryje też różne znaczenia miłości (erotycznej, przyjacielskiej i zdolnej do poświęcenia), nie wykluczając funkcji prokreacyjnej mężczyzny i kobiety.

Osoba jest bytem wolnym w stosunku do własnej ekspresji seksualnej. Oznacza to, że potrafi odróżnić to, co jest determinizmem, od tego, co jest plastycznościa popędu, wraz z jego korelatami psychicznymi i duchowymi. Osobie odsłania się różnica między pożądaniem i pragnieniem, siłą popędu i zdolnością do jego sublimacji, nie mówiąc o zdolności do integracji osobowej seksualności. Proces integracji jest zadaniem niełatwym, zwłaszcza w społeczeństwie rozerotyzowanym poprzez pornografię. Jest jednak konieczny w tworzeniu tożsamości płciowej człowieka. Bez tego nie nastąpi integracja biologicznej siły seksu, psychicznej przyjemności towarzyszącej jego ekspresji oraz wartości moralnych, jakie jednostka chce osiągnąć w życiu. Dlatego nie tylko można, ale należy mówić o odpowiedzialności za własną naturę płciową, za drugiego człowieka i relacje seksualne między kobietą i mężczyzną.

Osoba wreszcie przeżywa swoją seksualność w kontekście społecznym, którego najbardziej elementarnym wyrazem jest komplementarność płci. Na tej płaszczyźnie płciowość mężczyzny i płciowość kobiety wchodzą w sieć odniesień, które mogą osiągnąć poziom wzajemnego zatroskania kierowanego poprzez miłość poświęcenia, choć są też narażone na wyzysk, krzywdę i poniżanie. W tym drugim przypadku mogą powstawać stereotypy, nierówne traktowanie, a nawet przemoc wobec kobiet obciążonych obowiązkami macierzyńskimi. Dlatego osobowe podejście do relacji między płciami zakłada sprawiedliwość struktur społecznych i kulturowych oraz kładzie nacisk na rolę sumienia. 
Wydaje się, że takie podejście do płciowości nie gubi niczego z intuicji K. Wojtyły, wyrażonej w Osobie i czynie ${ }^{17}$. Stwarza też szansę do dialogu z bardziej doświadczalnym, fenomenologicznym opisem człowieka $^{18}$. W istocie kard. Wojtyła, później papież Jan Paweł II, otworzył podstawy do realistycznego opisu istoty męskości i kobiecości. Uwzględnia on społeczne uwarunkowania płci, uzasadniając ich równość w pogłębionym religijnie rozumieniu cielesności i miłości. Na takiej drodze łączenia biologii, psychiki i kultury płciowości ludzkiej nie redukuje się żadnego elementu płciowości. Nie idzie się też na skróty, co - jak się wydaje - ma miejsce w myśleniu radykalnych feministek. Właściwie odczytany zamysł Boga wobec kobiety i mężczyzny potwierdza osobową interpretację struktury cielesności ludzkiej, zakotwiczając jej ostatecznościowe uzasadnienie w woli Boga, który jest miłością.

Dla zatroskanych o rodzinę oznacza to podwójne zadanie. Po pierwsze, należy badać rzeczywistość małżeństwa i rodziny w sposób integralny; począwszy od rzetelnej analizy struktury biologicznej, psychicznej, aż po duchowo-religijne wymiary podmiotów życia małżeńsko-rodzinnego. Po drugie, nie trzeba wykluczać z tej struktury znaczenia miłości. Nie chodzi tylko o miłość jako siłę psychiczno-moralną, która łączy osobę kobiety i mężczyzny, lecz także o miłość jako cnotę społeczną, zakładającą powinność budowania sprawiedliwych struktur społecznych, w których żyją kobieta i mężczyzna. Stąd wypływa najczystszy impuls do budowania równości między nimi. Należy zadbać o jej kulturowy, społeczny, ekonomiczny i polityczny wyraz.

Miłość nie dekonstruuje natury płci, nie wprowadza walki między kobietą i mężczyzną, nie zatraca się w parodii. Wsłuchując się w głos sumienia konkretnej kobiety i konkretnego mężczyzny, miłość motywuje do usuwania nierówności oraz wynosi ich do takiego

\footnotetext{
17 Por. K. Woj t yła, Osoba i czyn, Kraków 1969.

18 Por. W. C h u d y, Obszary filozoficzne Jana Pawła II teologii ciała, w: T. S t y c z e ń (red.), Jan Pawet II. Mężczyzna i niewiasta stworzyt ich. Chrystus odwotuje się do ,poczatku”. O Jana Pawła II teologii ciała, Lublin 1981, s. 228.
} 
zjednoczenia, które Biblia nazywa byciem w jednym ciele. Miłość jest podstawą klarownej wizji człowieka, o której powstawaniu Buttiglione pisze tak: „Nie istnieje (jakaś) struktura biologiczna aktu i (jakaś) decyzja wewnętrzna podmiotu, który traktuje akt (tylko) z punktu widzenia jego skutków. Pomiędzy płaszczyzną biologiczną i duchową włącza się - i niejako obie w jedna całość złącza i jako jedną całość wyraża - inna jeszcze płaszczyzna. W niej właśnie dochodzi do głosu przedmiotowe znaczenie, obiektywny sens aktu"19.

\section{ROLA WSPÓLCZESNYCH NAUK O CZLOWIEKU W OBRONIE RODZINY}

Umiejętność wykorzystania współczesnych nauk o człowieku i integracja ich wyników z tym, co typowo ludzkie, a więc adekwatną antropologią, jest łatwiejsze w sferze postulatów niż realizacji. Klasyczna filozofia zbyt długo była nieufna wobec interdyscyplinarnego dialogu, natomiast współczesny postmodernizm staje się bezradny. Pocieszające jest to, że ze strony niektórych przedstawicieli nauk o człowieku odzywają się głosy wołające o taką realistyczną antropologię. W kontekście naszej dyskusji warto zanotować głos Ryszarda Stachowskiego, ${ }^{20}$ który jest profesorem psychologii w Instytucie Psychologii Uniwersytetu im. Adama Mickiewicza.

Obserwując wzrastającą rolę psychologii w terapii małżeńskiej, warto spojrzeć na tę naukę z perspektywy wewnętrznych podziałów, jakie można dostrzec $\mathrm{w}$ jej ponad stuletniej historii. Jednym z powodów tych podziałów jest różnorodność obrazu człowieka, jaki można odkryć w konstruowanych przez poszczególne szkoły teoriach, począwszy od psychoanalizy poprzez psychologię humanistyczną, kończąc na psychologii chrześcijańskiej. Dla niektórych

19 R. B u t t i g l i o n e, Dar ciata darem osoby. Autonomia sumienia wobec autonomii prawdy, w: T. S t y c z eń (red.), Jan Paweł II. Mężczyzna i niewiasta stworzyt ich ..., dz. cyt., s. 157.

${ }^{20}$ Por. R. S t a c h o w s k i, Psychologia w ludzkiej perspektywie i personalizm Karola Wojtyly, „Nauka” 2005, nr 3, s. $105-138$. 
ilość tych szkól jest powodem do dumy i świadczy o dynamizmie rozwojowym psychologii. Stachowski jednak z troską patrzy na jej współczesny stan. Zresztą na początku artykułu przywołuje opinię T. H. Leahey'a, zmartwionego tym, ze psychologia amerykańska, świętująca stulecie Amerykańskiego Towarzystwa Psychologicznego, podzielona jest na mocno skłócone frakcje, obwiniające się nawzajem o działania w złej woli.

Główną przyczyną tego skłócenia jest - według Stachowskiego zbyt silne związanie się psychologii z materialistycznym i mechanicystyczno- pozytywistycznym obrazem nauki w XIX w. Do dzisiaj psychologia nie uporała się z problemem niezgodności przedmiotu swoich badań - którym jest człowiek - z przyrodniczym sposobem jego badania. Dla niektórych owa niezgodność ,,jest wskazówką, iż założenia przyrodniczo-naukowego podejścia nie są odpowiednie dla jedynego w swoim rodzaju przedmiotu psychologii, a zatem konieczna jest odmienna koncepcja psychologii jako nauki (...) tak, aby mogła ona objąć fenomeny ludzkie na sposób, który jest istotny z punktu widzenia psychologii (...). Ci, którzy w pełni akceptują przyrodniczo-naukowe podejście w psychologii, zawsze czują się poniekąd zobowiązani do uzasadnienia, że psychologia jest nauką i w dodatku zawsze uznają za konieczne modyfikowanie i przekształcanie, często w sposób zasadniczy, metod nauk przyrodniczych. Gdyby psychologia w sposób oczywisty była nauką przyrodniczą, czy byłyby konieczne te uzasadnienia i czy tych metod nie można byłoby przejąć z pomniejszymi tylko modyfikacjami” ${ }^{21}$.

Dążenie do wpisania psychologii na listę nauk przyrodniczych owocowało odcięciem jej od antropologii filozoficznej. Prof. Stachowski tłumaczy to tym, że psychologowie nie mieli się do kogo zwrócić po filozoficzną antropologię, gdyż sama filozofia w dużej części zrezygnowała z poszukiwania takiej antropologii. Wśród wyjątków byli przedstawiciele niemieckiej antropologii filozoficznej: M. Scheler,

${ }^{21}$ A. Gor g i, Psychologia jako nauka empiryczna uprawiana z ludzkiej perspektywy. Podejście fenomenologiczne, Białystok 2002, s. 83-84. 
H. Plessner i A. Gehlen ${ }^{22}$. Ich dzieła pojawiły się na początku lat dwudziestych ubiegłego wieku w sytuacji, kiedy wzrost wiedzy empirycznej o człowieku spotkał się z kryzysem jego tożsamości. To spotkanie filozofii i nauki nie wszystkich zadowoliło, ale nie można przecież zapomnieć otwarcia K. Wojtyły na pisma M. Schelera.

Zastanawiające jest to, że większość prób zbudowania antropologii otwartej na nauki o człowieku, ale uwzględniającej duchowość człowieka, lokalizuje się wokół personalizmu, podkreślającego podmiotowość człowieka. Tego samego szukają niektórzy psychologowie współcześni. Grupa polskich psychologów podjęła próbę wypracowania ,humanistycznego modelu psychologii jako nauki respektującej antropologiczną tezę o osobowym charakterze człowieka oraz stawiającej sobie za cel uchwycenie i opisanie przejawów osobowego życia w postaci wewnętrznego, subiektywnego doświadczenia"23. Wspomniani psychologowie nawiązali do europejskiej myśli egzystencjalnej, której przedstawicielami są Ludwig Binswanger, Medard Boss i Viktor Frankl. Każdy z nich akcentuje różne doświadczenia podstawowe człowieka, począwszy od pytania i poznawania, poprzez dążenie do prawdy, wolności, miłości, rzeczowości i twórczości, aż po sytuacje graniczne Jaspera, trwogę i troskę Heideggera czy stosunek ja do ty Bubera $^{24}$.

22 Por. Z. K r a s n o d ę b s k i, Ekscentryczność człowieka. O idei antropologii filozoficznej, w: H. P l e s s n e r, Pytanie o conditio humana. Wybór pism, Warszawa 1988, s. 3-15.; M. S c h e 11 e r, Pisma z antropologii filozoficznej i teorii wiedzy, (tłum., Wstęp, przypisy S. Czerniak, A. Węgrzecki), Warszawa 1977; A. G e h 1 e n, Der Mensch. Seine Natur und seine Stellung in der Welt, Wiesbaden 1986.

${ }^{23}$ I. M roc z k ow s k i, Osoba i cielesność. Moralne aspekty teologii ciała, Warszawa 2008, s. 8. Z zupełnie innej perspektywy K. Obuchowski stwierdza: „Człowiek w psychologii takiej, jaką w naszym kraju uprawiamy, nie jest podmiotem. Jest przedmiotem uruchamianym przez własne mechanizmy psychologiczne, przez sytuacje w jakie trafia, a jego świadomość, to, jak się sam określa, jego intencjonalność, powikłania w rozumieniu źródeł własnych decyzji - wydają się bez znaczenia”. Tenże, W poszukiwaniu właściwości człowieka, Warszawa 1989, s. 115 .

${ }^{24}$ Por. A. S i e m i a n o w s k i, Antropologia filozoficzna, Gniezno 1966, s. 45. 
K. Wojtyła, poszukując adekwatnej filozofii człowieka, nieprzypadkowo skierował swoją uwagę na system M. Schelera. Fenomenologia Schelera mówiła bowiem o osobie, uwydatniała znaczenie miłości do osoby oraz akcentowała rolę wychowania poprzez naśladowanie etycznego wzoru. Nie przesądzając w tej chwili o innych doświadczeniach bazowych dla osoby, warto sobie uświadomić, jakie znaczenie mogą mieć antropologiczne poszukiwania K. Wojtyły dla studiów nad rodziną. Analizy z Osoby i czynu oraz Miłości i odpowiedzialności mogą być przedmiotem badań nie tylko etyków, teologów i antropologów, ale - jak postuluje R. Stachowski - także psychologów. Sposób integrowania wiedzy przyrodniczej i humanistycznej przez K. Wojtyłę może zainteresować tak samo lekarzy, jak i przedstawicieli nauk społecznych. Ważna jest wrażliwość na to, co istotne w naturze ludzkiej, a co Papież nazywał <zjawiskiem ludzkim>. Jeśli z takim nastawieniem czyta się współczesne prace genetyków, psychologów, socjologów i neurobiologów, łatwiej jest precyzyjnie opisać uwarunkowania życia rodzinnego oraz znaleźć konkretne sposoby terapii rodzinnej.

\section{EKLEZJALNA STRATEGIA OBRONY RODZINY}

Obrońcy rodziny w Europie najczęściej wskazują dramatyczne skutki kryzysu demograficznego, jaki dotyka Europę. Według niektórych obliczeń w pierwszej połowie obecnego wieku ubędzie $20 \%$ Polaków, 35\% Bułgarów, 25 \% Rosjan. Do krajów zachodnich Europy przybywa każdego roku ok. 1,2 miliona. imigrantów ${ }^{25}$. Demografowie - podobnie jak socjologowie - patrzą na te fakty okiem chłodnego obserwatora. Sami zresztą nieraz się mylili; choćby w sprawie bomby demograficznej, którą straszono nas przed trzydziestu laty. Także dzisiejsze pesymistyczne prognozy niektórzy traktują jako przesadzone. Poważnie jednak traktują twierdzenia demografów

${ }_{25}$ Por. J. K r u p s k a, Polityka rodzinna $w$ Polsce $i$ w Europie, „Wiadomości KAI", 2008 nr 835, s. 30-34. 
zarządzający funduszami emerytalnymi, licząc się z coraz większymi kosztami starzenia się społeczeństwa.

W tej sytuacji należy zwrócić uwagę na charakter kościelnej obrony rodziny. Nie chodzi w nim w pierwszym rzędzie o poprawienie demografii. O to martwią się politycy ${ }^{26}$. Kościołowi powinno chodzić o obronę rodziny ze względu na jej wartość samą w sobie, chcianą przez Boga głęboka wspólnotę życia i miłości matżeńskiej. Chociaż więc kryzys demograficzny obejmuje cały kontynent, ${ }^{27}$ to zdecydowanymi obrońcami rodziny są przede wszystkim katolicy. Realistycznie patrząc, nie można liczyć, że przeciwnicy chrześcijaństwa wesprą Kościół w obronie rodziny.

W Polsce, dwadzieścia pięć lat po transformacji ustrojowej, nie doczekaliśmy się konsekwentnej polityki prorodzinnej. Jej losy podobne są do historii szkolnego wychowania do życia w rodzinie. Raz jest traktowane jako wychowanie seksualne, innym razem jako uczenie prorodzinnych zachowań. Po jednych wyborach parlamentarnych jest wprowadzane do szkół, po następnych modyfikowane i zapominane. Sama polityka rodzinna nie może ograniczać się do zbioru chwytliwych haseł wyborczych, odkładanych do lamusa po wyborach. Nie można ograniczać jej do polityki socjalnej, czyli pomocy społecznej skierowanej do rodzin stojących na granicy ubóstwa. Taka polityka utrwala postawy roszczeniowe, uczy bierności, stawia rodziny w roli proszących o jałmużnę. Rodzinom nie powinno się dawać jałmużny, ale prowadzić prorodzinną politykę podatkową, szkolną i społeczną.

Powtarza się w Polsce paradoks europejski polegający na tym, że „akurat w okresie, w którym Europejczycy mogli sobie pozwolić na

${ }^{26}$ Najbardziej rozwinięta polityka prodemograficzna nie wystarczy. Tylko na krótką metę poprawi przyrost naturalny. Tak dzieje się ostatnio we Francji i w Szwecji, gdzie w porównaniu z innymi krajami europejskimi przyjęto programy skutkujące poważną pomocą dla rodzin posiadających dzieci. Po krótkotrwałym wzroście liczba urodzeń ponownie zmalała. Jednocześnie sama instytucja rodziny przeżywa poważny kryzys, nie mniejszy niż w innych krajach, gdzie nie ma dotacji na dzieci. Por. W. L a q u e u r, Ostatni spacer po starej Europie, „Dziennik - Europa”, 2 maja 2008, nr 18, s. 10.

27 Por. tamże, s. 9. 
posiadanie większej liczby dzieci niż kiedykolwiek w przeszłości, mieli ich o wiele mniej" ${ }^{28}$. W Polsce wzrost dochodu narodowego wiąże się z coraz gorszymi statystykami demograficznymi. Celna jest więc diagnoza Jana Pawła II, który w Familiaris consortio pisał, iż u korzeni słabej kondycji rodziny współczesnej „leży skażone pojęcie i przeżywanie wolności, rozumianej nie jako zdolność do realizowania prawdziwego zamysłu Bożego wobec małżeństwa i rodziny, ale jako autonomiczna siła, utwierdzająca $\mathrm{w}$ dążeniu do osiągnięcia własnego egoistycznego dobra, nierzadko przeciwko innym" 29 .

Kościół w Polsce jest więc wezwany do tego, aby uczynił troskę o rodzinę swoim priorytetowym zadaniem duszpasterskim. Jak na dłoni widać, ,że historia nie jest po prostu procesem, który z konieczności prowadzi ku lepszemu, lecz jest wynikiem wolności, a raczej walki pomiędzy przeciwstawnymi wolnościami, czyli według znanego określenia św. Augustyna - konfliktem między dwiema miłościami: miłością Boga, posuniętą aż do wzgardy sobą, i miłością siebie, posuniętą aż do pogardy Boga"30.

Rodzinne zmagania między dwiema miłościami mogą podjąć ludzie sumienia, którzy w przymierzu z Bożą Mądrością, potrafią obronić w sobie zdolność do miłowania. W konsekwencji zaangażowanie Kościoła w obronę rodziny powinno być kompleksowym działaniem na płaszczyźnie wychowawczej (wychowanie człowieka sumienia), w żywym środowisku wiary Kościoła (Boży zamysł wobec małżeństwa i rodziny), przy konstruktywnym choć krytycznym dialogu antropologicznym z wynikami współczesnych nauk o człowieku. Nie można też zaniedbać pomocy rodzinie, ani też przeoczyć znaczenia struktur społeczno - polityczno - kulturowych w których żyją rodziny.

W obecnej sytuacji w Polsce Kościół jest najlepiej przygotowany na dwóch pierwszych płaszczyznach. Nasz wysiłek katechetyczny, rekolekcyjny i sakramentalny przedstawia klarowny zamysł Boga

\footnotetext{
28 Tamże.

29 J a n P aw eł II, Familiaris consortio, nr 6, Watykan 1981.

30 Tamże.
} 
wobec małżeństwa i rodziny, podaje też jasną hierarchię wartości. Gorzej jest z chrześcijańską antropologią płciowości i tworzeniem społecznej kultury prorodzinnej. Chrześcijańska teologia ciała żeby mówić językiem Jana Pawła II - wymaga wyciągnięcia konsekwencji z dowartościowania płciowości w analizie osoby. Dlatego należy krytycznie podejmować dyskusję na temat różnic płciowych w perspektywie geniuszu kobiety, który bywa wykorzystywany, niedoceniany, a nade wszystko niezrozumiany.

Nie znaczy to, że strategia Kościoła w obronie rodziny może lekceważyć oświeceniowe, psychoanalityczne i marksistowskie korzenie współczesnych ideologii, które królują na nowych areopagach, czyli w świecie nauki, kultury, środków przekazu i edukacji. Trzeba to robić jednak kompetentnie, korzystając z pomocy wierzących socjologów, psychologów, filozofów. Wydziały uczelni katolickich powinny kształcić ludzi, którzy rozumieją współczesny świat, potrafią krytycznie ocenić trendy kulturowe, przygotowując w ten sposób argumenty dla biskupów podejmujących strategiczne decyzje w obronie rodziny ${ }^{31}$. Gdzie, jak nie w katolickich uczelniach, powinno się krytycznie analizować gender, dyskutować z różnorodnymi ruchami feministycznymi, analizować współczesne formy wykluczenia. Biskupi w swoim głosie sprzeciwu powinni mieć wsparcie specjalistów, zwłaszcza kiedy na ławie oskarżonych sadza się dziś nie tylko biskupów. Całe chrześcijaństwo oskarża się o to, że stało się źródłem wykluczenia, propaguje patriarchalną rodzinę, formuje osobowości autorytarne. Chrześcijańska tradycja jest oskarżana o to, że jest źródłem zacofania, moralność - o to, że przeszkadza samorealizacji, a patriotyzm-że szerzy nietolerancję ${ }^{32}$.

31 W tym kontekście warto przypomnieć List Biskupów na temat gender, który został odczytany z ambon w Uroczystość Świętej Rodziny w 2013 r. Nie negując konieczności powstania Listu czy tym bardziej prawa biskupów do zajęcia stanowiska na temat gender, sam problem powinien być pogłębiony poprzez krytyczne opracowanie specjalistów, a co najważniejsze przedstawiony tak, aby nie narażać się na uszczypliwe uwagi uczonych. Por. Uczeni do biskupów: Szanujcie naukę, „Gazeta Wyborcza”, 4-6 stycznia 2014, s. 3.

${ }_{32}$ Por. G. G ó r n y, Kto zdobędzie nowożytne areopagi?, „Rzeczpospolita PlusMinus", 10-11 maja 2008 r. s. A18. 
Katolicka strategia obrony rodziny nie wyczerpuje się oczywiście w dyskusji. Ważniejsze jest działanie, oparte na życiu sakramentalnym, świadectwie i konkretnej pomocy rodzinie. Znacznie więcej uwagi należy w Polsce poświęcić temu, za co G. Górny chwali katolików amerykańskich. „Liderzy środowisk katolickich i protestanckich w USA mówią wprost, że główna linia starcia cywilizacyjnego przebiega dziś przez redakcje, sądy, szkoły i uniwersytety, a stawką w toczącym się konflikcie jest nie tylko oblicze mediów, kształt prawa, czy sposób edukacji, ale przyszłość chrześcijaństwa. Dlatego tak wiele wierzących osób angażuje swoje środki, czas i energię, by budować i wspierać nowe instytucje w dziedzinie edukacji, prawa mediów"33.

Kościół w Polsce jako instytucja musi zdecydowanie więcej zaangażować się na tym polu. Wymaga to większego uświadomienia sobie odpowiedzialności wspólnotowej, realizowanej w nowych warunkach, przy konieczności tworzenia nowych instytucji. Kiedy żył Jan Paweł II, on stanowił centrum odniesień w kreatywnym myśleniu i działaniu większości biskupów, kapłanów i wiernych świeckich. Można mieć nadzieję, że zarówno wpływ papieża Franciszka, jak i ożywione poprzez nową ewangelizację polskie tradycje odpowiedzi na komunizm, pozwolą nam otrząsnąć się z marazmu i podjąć nowe wyzwania. Decydującą rolę odegrają wspólnoty, ruchy oraz stowarzyszenia rodzinne, a także parafie. Powinny one jednak uwalniać się od ociężałości strukturalnej, bronić przed odseparowaniem od ludzi czy - nie daj Boże - zasklepiać się w grupy wybranych, zapatrzonych w samych siebie ${ }^{34}$.

\footnotetext{
33 Tamże, s. A19.

${ }^{34}{ }^{34}$ Por. F r a n c i s z e k, Adhortacja apostolska Evangelii gaudium. O głoszeniu Ewangelii w dzisiejszym świecie, nr 28, Watykan 2013.
} 


\section{Streszczenie}

Zwracając uwagę na interdyscyplinarne aspekty w dyskursie o współczesnym kryzysie rodziny, autor artykułu odwołuje się zarówno do świadomości współczesnych rodziców, jak i dorobku naukowego S. Olejnika, najwybitniejszego teologa moralisty w Polsce w drugiej połowie XX w. Profesor od początku swojej działalności naukowej miał świadomość konieczności dialogu teologii moralnej nie tylko z innymi naukami teologicznymi, ale także z wynikami współczesnych nauk o człowieku.

W artykule akcentuje się zbieżność potrójnej perspektywy badawczej w teologii i psychologii Ph. Zimbardo. W teologii mówi się o statusie ontologicznym podmiotów życia rodzinnego, współczesnych uwarunkowaniach relacji małżeńskiej oraz kościelnej strategii obrony rodziny. Ph. Zimbardo, opisując kryzys ojcostwa, bada behawioralny kontekst jednostki i jej cechy, analizuje sytuację związaną z konkretnym społecznym i fizycznym środowiskiem oraz odsłania układ sił, który tworzy, podtrzymuje i modyfikuje sytuację.

Taki kontekst badawczy pozwala autorowi artykułu uwzględnić osobowa naturę kobiet i mężczyzn jako podmiotów życia rodzinnego, krytycznie podejść do redukcjonistycznego opisu sytuacji rodziny przez współczesne nauki oraz uwypuklić eklezjalny charakter układu sił, tworzących strategię obrony rodziny.

\section{Interdisciplinary Aspects of Theological Family Protection Summary}

Pointing out to the interdisciplinary aspects in the discourse on the contemporary family crisis, the author of the article refers both to the awareness of contemporary parents as well as to the scientific accomplishments of S. Olejnik, the most distinguished theologian and moralist in Poland of the second half of the 20th century. Professor, from the beginning of his scientific activity, was aware of the need for dialogue of moral theology not only with other theological sciences, but also with the results of contemporary human sciences.

The article emphasises the convergence of the triple research perspective in theology and psychology of Ph. Zimbardo. Theology speaks of the ontological status of the entities of family life, contemporary conditions of the marital relationship as well as church strategy for family protection. Ph. Zimbardo, describing the fatherhood crisis, examines the behavioural context of an individual and its features, analysing 
the situation connected with the particular social and physical environment as well as reveals the system of forces that creates, sustains and modifies the situation.

Such a research context allows the author of the article to consider the personal nature of women and men as entities of family life, apply a critical approach to the reductionist description of the family situation by the contemporary sciences as well as to emphasise the ecclesial nature of the system of forces forming the strategy for family protection.

\section{Bibliografia:}

Chudy W, Obszary filozoficzne Jana Pawła II teologii ciała, w: T. Styczeń (red.), Jan Pawet II, Mężczyzna i niewiasta stworzyt ich. Chrystus odwotuje się do „poczatku”. O Jana Pawła II teologii ciała, Lublin 1981, s. 217 - 238.

Franciszek, Adhortacja apostolska Evangelii gaudium, Watykan 2013.

Gehlen A., Der Mensch. Seine Natur und seine Stellung in der Welt, Wiesbaden 1986.

Gorgi A., Psychologia jako nauka empiryczna uprawiana z ludzkiej perspektywy. Podejście fenomenologiczne, Białystok 2002.

Imieliński K. (red.) Seksuologia. Zarys encyklopedyczny, Warszawa 1985.

Jan Paweł II, Adhortacja apostolska Familiaris consortio, Watykan 1981.

Jan Paweł II, Ojcostwo i macierzyństwo w zamyśle Bożym, „L'Osservatore Romano” (wyd. pol.) 1999, nr 11, s. 11-13.

Jan Paweł II, Encyklika Veritatis splendor, Watykan 1993.

Krasnodębski Z., Ekscentryczność człowieka. O idei antropologii filozoficznej, w:

H. Plessner, Pytanie o conditio humana. Wybór pism, Warszawa 1988, s. 3 - 15.

Mroczkowski I., Ocena dorobku naukowego i działalności na rzecz nauki i kultury chrześcijańskiej Księdza Profesora Stanisława Olejnika w związu z nadaniem doktoratu honoris causa, w: Ks. abp prof. Alfons Nossol, ks. prof. Stanistaw Olejnik. Doktorzy honoris causa i Papieskiego Wydziału Teologicznego we Wrocławiu, Wrocław 2007, s. 47-49.

Mroczkowski I., Osoba i cielesność. Moralne aspekty teologii ciała, Warszawa 2008.

Mroczkowski I., Natura osoby ludzkiej. Podstawy tożsamości człowieka, Płock 2012.

Mroczkowski I., Rodzina, gender i nowy feminizm. Podstawy chrześcijańskiej obrony i promocji rodziny, Płock 2014.

Obuchowski K., W poszukiwaniu właściwości człowieka, Warszawa 1989. 
Olejnik S., Eudajmonizm. Studium nad podstawami etyki, Warszawa 1954.

Scheller M., Pisma z antropologii filozoficznej i teorii wiedzy, Przełożyli, wstępem i przypisami opatrzyli S. Czerniak i A. Węgrzecki, Warszawa 1977.

Stachowski R, Psychologia w ludzkiej perspektywie i personalizm Karola Wojtyły, „Nauka”, 2005 nr 3, s. 105-138.

Wojtyła K, Osoba i czyn, Kraków 1969.

Wilski T, „Tajemnica osoby”- klucz do zrozumienia siebie i Boga, „Communio. Międzynarodowy Przegląd Teologiczny”, 1982 nr 2(8), s. 24-44.

Zimbardo Ph.G,. Coulombe N.S, Gdzie ci mężczyźni, (tłum.) M. Guzowska, Warszawa 2015. 